\title{
Effects of Schools' Physical Infrastructure on Student Discipline in Secondary Schools in Eldoret East Sub-County, Kenya
}

\author{
Jepkorir Chewen $^{1 *}$, Jennifer Munyua ${ }^{2}$, Shadrack Ogoma ${ }^{2}$
}

${ }^{1}$ Catholic University of Eastern Africa, GABA Campus, P.O. Box 908-30100, Eldoret, Kenya

${ }^{2}$ Faculty of Education, Catholic University of Eastern Africa

DOI: $10.36347 /$ sjahss.2020.v08i06.003

| Received: 02.06.2020 | Accepted: 10.06.2020 | Published: 13.06.2020

*Corresponding author: Jepkorir Chewen

Abstract

The intentions of this enquiry were to examine the consequences of physical infrastructure on indiscipline practices among learners in secondary schools in Eldoret East Sub-County, Kenya. This was in the light of the concern that an increased number of student indiscipline cases in the nation, which included strikes and setting blaze school facilities, had been reported. The study was guided by Social Control Theory. Ex-post facto research design was used and a sample of 346 students and 54 deputy principals took part in the study. Questionnaires and interview schedule were used to collect data. Descriptive statistics was evaluated in form of frequencies, percentages, average and standard variation. ANOVA was used to test the hypotheses. The status of physical infrastructures $(\mathrm{F}[27,293]=1.142, \mathrm{p}=$ .290). The study concluded that the status of physical infrastructure had no effect on indiscipline cases in Eldoret East Sub-County. The study recommended that schools should look into other factors that may lead to indiscipline among secondary school students and that schools with limited resources should put more emphasis on school regulations to reduce indiscipline.

Keywords: Effects of physical infrastructure, Indiscipline, students, Secondary schools, Eldoret East, Kenya.

Copyright @ 2020: This is an open-access article distributed under the terms of the Creative Commons Attribution license which permits unrestricted use, distribution, and reproduction in any medium for non-commercial use (NonCommercial, or CC-BY-NC) provided the original author and source are credited.

\section{INTRODUCTION}

Physical infrastructure includes all the tangible or concrete facilities in a school and are part of a school environment. These facilities include buildings such as classrooms, grounds, furniture and apparatus along with equipment necessary for imparting knowledge in the learners. Ideally, schools should be set up in a suitable environment where there is plenty of space with trees to provide shade, a place far away from distractive noise, preferably away from congested towns and pollution. For learning to take place, a school should have enough space, adequate lighting, comfortable seating, enough library, playground, classrooms and ablution facilities.

In Kenyan secondary schools, physical infrastructure is adequate in some schools while in some the situation is characterized by lack of adequate classrooms leading to crowding. Even in schools with enough facilities, the buildings are characterized by leaking roofs, the number of toilets and latrines are not enough for all the learners as required by the Safety Standards Manual. Muratha, in her study on schoolbased factors and their effects on discipline, showed that teaching and learning facilities have an influence on discipline [1]. This is an indication that availability of adequate physical infrastructure could assist in enhancing discipline among students and prevent problematic behaviour.

Peterson and Skiba, in their study, indicated that school surroundings influence the complete outlook that teachers and learners have about their school, where the surrounding include all the facilities within the school [2]. These feelings help in showing the level of satisfaction that each individual has about their school. Therefore, the school surroundings could either promote or discourage learners socially, morally and psychologically. These were linked to students' indiscipline behaviours such as delinquency, truancy and substance abuse.

\section{State of Physical Infrastructure and Students' Discipline Problems}

Parents take their children to learning institutions hoping that the children will benefit from the teaching/learning process and be able to reap maximum profit from school experiences. Therefore, parents expect their children's learning to be meaningful, successful, purposeful and profitable. 
However, sometimes this aim is not achieved so that children engage in deviant acts, resulting in wastage of resources. Many factors engender deviant behaviour among learners in school. Among these factors are those related to school infrastructure?

According to a report by UNESCO, in France, Norway and Brazil, students were bored because teachers were unable to give them individual attention due to their large numbers per class [3]. As a result, students' interest in classroom activities reduced. In Algeria, Sudan and Nigeria, the situation was just as bad where secondary school classrooms averaged 50 students per class after the government introduced free and compulsory basic education. Consequences of such an increment included a drop in the standards of teaching, reduction in student-teacher interactions, an increase in academic failure as evidenced by high number of students repeating classes and increased learner school drop-outs, among others.

Wang, Selman, Dishion and Stormshak conducted a study to examine students' perception of school's physical outlook and behavioural problems in China [4]. The purpose of the study was to find out how academic focus, discipline and order, peer relationships, and student-teacher relationships were interlinked. Therefore, the study, first, sought to find out students' with more positive viewpoint about the schools physical outlook at sixth grade had lower chances of indulging in problem behaviour in the seventh and eighth grade. Secondly, for those who take part in problem behaviour, the study sought to find out if those with more positive perception at sixth grade engaged in less problem behaviour in seventh and eighth grade. Finally, it investigated if students' gender regulated the connection between students' present perceptions of school's physical outlook and the subsequent problem behaviour. The study engaged longitudinal survey research design. A sample of 677 students participated in the study. A rating system that involved social skills for students to self-report behavioural record was employed as data compilation instrument. Teachers were also given a reporting sheet, and finally the teachers and students findings were compared.

The responses from the students' self-reporting proofed to be reasonably reliable [4]. The study found that students who perceived a more positive physical outlook of the school in sixth grade had a lower probability of experiencing problem behaviours in seventh and eighth grade. Additionally, Wang et al. reported that positive student-teacher relationships and discipline and order were more substantially linked with lesser probability that a young person would take part in problem behaviour. The relationship between school's physical outlook and gender was not statistically significant. The conclusion from the study was that because adolescents' viewpoints on school are physical outlook was a strong predictor of problem behaviour, it was important to ensure that a positive school environment existed. There commendations were that schools with limited resources should put more emphasis on school regulation, order, and studentteacher relationships to reduce problem behaviours.

Malinen and Savolainen carried out a study to investigate the consequence of teachers' perceived school's physical outlook on behaviour management among students in Finland [5]. The study used longitudinal survey research design. A total of 642 high school teachers were targeted for the study. A teachers' questionnaire was used to collect data from the respondents. The study indicated that behaviour management among students was positively affected by school's physical outlook. The reviewed study was administered in Finland, a developed country, while the current study was conducted in Kenya which is still a developing country. The reviewed study paid attention to how teachers' views on school's physical outlook influenced behaviour management among students in secondary schools. However, the present study was more concerned with the effect of school's physical outlook on indiscipline among secondary school students.

Katz and Blagg executed a study to evaluate the environment of the learning institutions and discipline tools owing to the fact that student discipline and school environment had become a national discourse [6]. Differences existed between the rates of exclusion and dismissal of black and white students in which more blacks were being suspended and expelled from secondary schools compared to white students. There was also a high-profile incident of discrimination by teachers in secondary schools. For example, a black student was thrown on the floor by a sheriff's deputy in a South Carolina classroom. In tandem with increased discussion on the utilization of suspensions and expulsions, initially, there was an increased focus on measuring and tracking how schools handled discipline. The study by Katz and Blagg further looked into the school environment and discipline landscape, and assessed the availability of information on these matters such that parents could apply in making school preference decisions and that the public could use to hold schools more answerable. The study confirmed that schools had improved on standardized school discipline reporting, and discipline rates had dropped across the board at elementary, middle, and high schools. While the reporting and dissemination of the statistics concerning the discipline of the school had made significant progress, schools could further improve their way of reporting information about school environment. The study suggested that all schools need to concentrate on improving school environment and discipline reporting and monitoring to meet the requirements of parents, schools, and policymakers. 
Cornell, Shukla and Konold conducted a study to look into the consequences of authoritative school environment and students learning activities, scores and expectations in middle and high schools in Virginia, USA [7]. The study carried out trials on authoritative school environment that was identified by how restorative formation on the students was favourable to good academic results as far as middle high school students were concerned. Multilevel multivariate modelling was executed through surveys completed by a large sample that was split into two. In line with the theory of Authoritative School Climate, both elevated corrective organization and student support were linked with higher student commitment while at school, higher end results after testing, and higher educational ambitions at the level of the students in both sample groups. At the school level, increased corrective structure was connected with higher engagement, and student support was related with higher engagement and scores in both groups. The summary of the results introduced new proof that an authoritative school environment was favourable to student performance in their academic work in schools. The evaluated study concentrated on the effect of school's environment on academic performance and engagement while the current study focused on the consequences of schools' physical infrastructure on disruptive behaviour among students in secondary schools. The reviewed study employed longitudinal survey research design while the current study employed causal comparative research design.

A study that was done in America by the National School Climate Centre found that the physical state of a learning institution could impact learners' achievement [8]. The study also noted that several features of a school building could also affect learning, including spatial configurations, noise, school compound and school buildings. Learners needed clean air, good lighting, quiet and comfortable classrooms, which in turn encouraged the students to achieve their highest levels. The organization of classrooms, including the arrangement of furniture, could also impact student behaviour and learning by optimizing learning time, minimizing disruptions and keeping an organized and valuable environment for learning [8].

Branham carried out a study at the higher institution of learning in Houston on the effects of inadequate school building facilities on student attendance [9]. The findings revealed that if a school is damaged and left unrepaired, the resultant disrepair would create an environment of instability which tended to strangle social order and the educational process. Moreover, students in such an environment believed that they were not extraordinary from others, that school was not important, that no one really cared for them or their fate, and for that reason would more likely stay home, giving education low priority in their lives or perform poorly in academics.
Cuyvers, De Weerd, Dupont, Mols and Nuytten conducted a study in Antwerp on the consequences of infrastructure [10]. The findings revealed that the quality of school facilities definitely had a strong impact on an individual students' wellbeing at school. This further influenced how students behaved in school.

Zander conducted a study to explore the links between school's physical environment and performance of the students in Chicago [11]. This was in the light of concern that the physical environment of a school had been widely renowned to be an important constituent of successful schools and a predictor of a variety of student results. Conversely, several debates were being carried out to find out whether school's physical environment should be thought of and investigated at the individual- or the school-level. The study used Hierarchical Linear Modelling to look into the association between $9^{\text {th }}$ grade students' point of view on school's physical environment and their schools' academic and behavioural performance. Multi-level methods helped to differentiate student- and schoollevel effects. In general, the findings suggested that school's physical environment concurrently affected students individually and collectively. The study also exposed the fact that the most of the variations in the scores from school's physical environment were within schools. Additionally, perceptions of each student on school's physical environment were more strongly linked to improved student outcomes than in collective categorization, particularly students' perceptions of teachers' prospects and school safety. The study paid more attention to the effect of school's physical environment on students' academic achievements while the current study focused on the effect of school's physical infrastructure on indiscipline.

Owoeye and Yara conducted a study to investigate the number of learners in a class and academic attainment of secondary school in Ekiti State, Nigeria [12]. The study engaged survey research design. The studied population was 50 high schools from the countryside and town areas of the state. The data collection tool was the Students' Class Size Questionnaire (SCSQ) that was used to collect information from students. A single premise was developed and tested. Data obtained from the study was analysed using averages and t-test. The result indicated that there was no significant disparity in the academic outcomes when students were in smaller or in larger classes from urban schools $(t=1.49 ; \mathrm{p}<0.05)$. It also became clear that there was no significant difference between achievements obtained by students from rural bigger and rural smaller classes $(t=0.58 ; \mathrm{p}<0.05)$.

It was suggested those involved in the process of setting educational guidelines in government should make sure that more learning rooms were constructed and number of students occupying one class should not 
exceed 30. The Parent Teacher Association (PTA), philanthropists and other charitable organizations were also beseeched to support the government to enhance students' performance in SSCE by creating additional classrooms and other necessary structures. While the examined study was carried out in Nigeria, the current one was conducted in Kenya. In addition, the reviewed study was concerned with the effect of class size on students' academic performance while the current study concentrated on the effect of school's physical infrastructure on indiscipline among secondary school students.

Mwaura undertook a study on the efficiency of Kenyan Education Sector Support Programme grants on improvement of infrastructure in primary school in Kiambu District [13]. The results indicated that there was a shortage of infrastructure and existing facilities were not in good conditions thus leading to poor working environments. As reported by Mwaura, field surveys conducted by the Ministry of Education had revealed that poor primary school infrastructure was one of the main constraints to improving access to primary education in Kenya.

Following the governments' introduction of free basic Education in 2003, additional pressure was added to existing school infrastructure. The results of the sharp rise in number were poor setting and congestion which are not favourable to good learning environment [14]. School buildings in a number of countries are in a poor state. For example, most Kenyan schools have badly constructed classrooms and playgrounds, inadequate and defective toilet facilities, gender insensitive location of toilets and ablution facilities, and inadequate and unsuitable desks and other equipment. School buildings in public primary schools need repair and maintenance in order to create attractive teaching/learning environments for teachers and learners [15].

\section{Statement of the Problem}

The condition of students' indiscipline in Kenyan secondary schools is disheartening as an increase in violent behaviour incidences have been noted recently [16]. The explanation given for these incidences includes teenage misbehaviour, drug abuse and peer pressure. Despite the government efforts to impose discipline in Kenyan schools, recurrent unrest in schools has been reported. The fact is that student unrests in Kenya have taken new dimensions. Apart from forceful attacks and destruction of properties, they seem well-planned to cause serious damage to people's lives physically, emotionally and psychologically.

The climax of student unrest in Kenya was seen in 2016 when, in a span of 6 months, students razed down more than 100 schools. A good number of the unrests involved burning of school dormitories, which resulted in extensive loss of property and, in some incidences, loss of life. The arson incidences were undertaken mainly by students. The indiscipline practices were not exclusive to particular parts of the country. In 2016, Uasin Gishu County registered seven incidences of disruptive behaviour.

Many studies have been undertaken in relation to school's physical environment and indiscipline. The physical environment in these studies encompasses the physical infrastructure. For example, in developed countries, Linares explored the effects of school's physical environment on students' success and discipline in three urban high schools in Houston and Texas [17]. Wang et al. also investigated students' supposed school's physical environment and etiquette problems in China [4]. In Kenya, Wairagu focused on factors that directly related to the school and affected indiscipline practices in Thika West Sub-County [18]. Similarly, Okendo, Nganzi and Munyua undertook a study to examine how school's physical environment affected students' academic outcomes in Kisii County [19]. None of these studies carried out earlier paid attention to the effect of school infrastructure on students' indiscipline in secondary school. Thus, the study was carried out to find out whether school infrastructure affected indiscipline with the aim of suggesting ways to reduce indiscipline cases.

\section{MATERIALS AND METHODS}

The study used ex-post facto research design and sought to investigate the effect of schools' physical environment on indiscipline among secondary school students in Eldoret East Sub-County, Kenya. Target population for the study included 3480 Form Three students in 54 secondary schools in the Sub-County. The population was made up of mixed day and boarding secondary schools, boys' and girls' boarding secondary schools.

The sample size was determined using the Krejcie and Morgan table [20]. The study used stratified and simple random sampling techniques to select a sample of the 346 students. Interview schedule was used to obtain in-depth understanding on the issue under study. Data collected from the study was edited, coded and entries were made into statistical software (SPSS). It also involved converting quantitative data into mathematical codes. Qualitative data was sorted, coded and analysed in form of themes. Finally, the results were presented in frequency tables and percentages. Descriptive statistics consisted of frequencies, percentages, means and standard deviation to summarize the data. ANOVA was employed to test the hypotheses.

\section{RESULTS AND DISCUSSION}

The study sought to investigate the influence of the state of physical infrastructure on indiscipline among students in secondary school in Eldoret East Sub-County. The objective was realized by, first, asking 
the students to indicate their level of agreement or disagreement with the current state of physical infrastructure in their schools. The statements were scored using a set of eight statements developed and rated on a 5 point Likert scale ranging from; $5=$ strongly agree to $1=$ strongly disagree. The results were as summarized in Table 1.

Table-1: State of Schools' Physical Infrastructure in Eldoret East Sub-County

\begin{tabular}{|c|c|c|c|c|c|c|c|}
\hline Statement & $\begin{array}{l}\text { SD } \\
\text { F(\%) }\end{array}$ & $\begin{array}{l}\text { D } \\
\text { F }(\%)\end{array}$ & $\begin{array}{l}\mathrm{U} \\
\mathbf{F}(\%)\end{array}$ & $\begin{array}{l}\mathbf{A} \\
\mathbf{F}(\%)\end{array}$ & $\begin{array}{l}\text { SA } \\
\text { F(\%) }\end{array}$ & Mean & SD \\
\hline $\begin{array}{l}\text { My school has enough } \\
\text { classrooms }\end{array}$ & $45(14.0)$ & $45(14.0)$ & $28(8.7)$ & $119(37.1)$ & $84(26.2)$ & 3.83 & 1.40 \\
\hline $\begin{array}{l}\text { The classroom are well } \\
\text { ventilated and spaced }\end{array}$ & $31(9.7)$ & $33(10.3)$ & $18(5.6)$ & $118(36.8)$ & $121(37.7)$ & 3.47 & 1.38 \\
\hline $\begin{array}{l}\text { The wall in our school are } \\
\text { painted and maintained on } \\
\text { yearly basis }\end{array}$ & $80(24.9)$ & $67(20.9)$ & $39(12.1)$ & $71(22.1)$ & 64(19.9) & 2.91 & 1.49 \\
\hline Our school has piped water & $45(14.0)$ & $29(9.0)$ & $27(8.4)$ & $117(36.4)$ & $103(32.1)$ & 3.6 & 1.38 \\
\hline $\begin{array}{l}\text { The pavement in our school are } \\
\text { cemented }\end{array}$ & $81(25.2)$ & $28(8.7)$ & $24(7.5)$ & $98(30.5)$ & $90(28.0)$ & 3.27 & 1.57 \\
\hline $\begin{array}{l}\text { The dining hall in our school is } \\
\text { large and adequate to cater for } \\
\text { all the students. }\end{array}$ & $97(30.2)$ & $45(14.0)$ & $22(6.9)$ & $61(19.0)$ & $96(29.9)$ & 3.04 & 1.66 \\
\hline $\begin{array}{l}\text { The dormitories are adequate } \\
\text { for all the students }\end{array}$ & $97(30.2)$ & $45(14.0)$ & $22(6.9)$ & $61(19.0)$ & $96(29.9)$ & 3.11 & 1.62 \\
\hline
\end{tabular}

Source: Survey Data (2018)

As shown in Table 1, the results revealed that majority of the schools had enough classrooms as shown by $(M e a n=3.83$ and $\mathrm{SD}=1.40)$. Moreover, the schools had piped water (Mean=3.6 and $\mathrm{SD}=1.38$ ) and the classrooms were well ventilated and spaced (Mean=3.47 and $\mathrm{SD}=1.38$ ). The pavements in most of the schools were also cemented (Mean=3.27 and $\mathrm{SD}=1.57$ ) and the dormitories were adequate for all the students (Mean=3.11 and $\mathrm{SD}=1.62$ ). Additionally, the dining halls were large and adequate to cater for all the students (Mean=3.04 and SD=1.66). However, majority of the students disagreed that the walls in their schools were painted and maintained on yearly basis as indicated by (Mean=2.91 and $\mathrm{SD}=1.49)$. Based on these findings, it was deduced that majority of the schools' physical infrastructures were in good condition to provide the students with a favourable schools' physical infrastructure. Considering these findings, therefore, it was possible that indiscipline in schools in Eldoret East Sub-County was not attributable to poor physical infrastructures.
The Deputy Principals were also interviewed concerning the state of physical resources in their schools. One of the Deputy Principals had this to say in response:

The status of physical infrastructures is not a cause of indiscipline in secondary schools. The Deputy highlighted that majority of the schools have all the required infrastructural facilities required for positive school climate (Deputy Principal, Personal Communication, 2018).

To evaluate the effect of status of physical infrastructures on indiscipline cases, ANOVA was carried out on the following hypothesis:

$\boldsymbol{H}_{01}$ : There is no relationship between status of physical infrastructures and indiscipline cases in Eldoret East Sub-County.

The results were as presented in Table 2 below.

Table-2: ANOVA on State of Physical Infrastructures and Student Indiscipline

\begin{tabular}{|l|l|l|l|l|l|}
\hline Source of variations & Sum of squares & Df & Mean square & F & Sig. \\
\hline Between groups & 2631.597 & 27 & 97.467 & 1.142 & .290 \\
\hline Within groups & 25011 & 293 & 85.364 & & \\
\hline Total & $\mathbf{2 7 6 4 3}$ & $\mathbf{3 2 0}$ & & & \\
\hline
\end{tabular}

Source: Survey Data (2018) 
The results in Table 2 show that $F(27,293)=$ $1.142, p=.290$. The $\mathrm{p}=.290$, which was greater than the level of significance 0.05 . Therefore, the research failed to reject the null hypothesis. The findings implied that the state of physical infrastructures in secondary schools had no effect on indiscipline cases among students in Eldoret East Sub-County. This showed that majority of the secondary schools in Eldoret East SubCounty had physical infrastructure that was enough and in good condition to support learning and overall student well-being in school.

The findings revealed that majority of the schools physical infrastructure were in good condition to provide the students with a favourable school physical infrastructure. From the findings, it was deduced that the indiscipline in the schools was not attributable to poor state of physical infrastructure. These findings supported those of Wang et al. regarding schools in China [4]. Wang et al. found that students who perceived a more positive school environment in sixth grade had a lower probability of experiencing problem behaviours in seventh and eighth grade. The study also established that schools that had limited physical resources experienced high rate of deviant behaviour among the students. The findings were also in line with the research results reported by Malinen and Savolainen on the consequence of teachers' perceived school environment on behaviour management among students in Finland [5]. The study indicated that behaviour management among students was positively affected by school environment, which constituted the physical facilities, teacher-students relationship and academic stress.

The findings also concurred with those of Katz and Blagg on school environment in learning institutions and discipline tools [6]. The study confirmed that schools had improved on standardized school discipline reporting, and discipline rates had dropped across the board at elementary, middle and high schools. While the reporting and dissemination of the statistics concerning the discipline of the school had made significant progress. The study suggested that all schools needed to concentrate on improving school environment and discipline reporting and monitoring to meet the requirements of parents, schools and policymakers.

The findings were also in tandem with those of Cornell et al. on consequence of authoritative school environment and students learning activities, scores and expectations in middle and high schools in Virginia [7]. At the school level, increased corrective structures were connected with higher engagement, and student support was related with higher engagement and scores in both groups. The summary of the results introduced new proof that an authoritative school environment was favourable to student performance in their academic work in schools.
The findings also concurred with Zander study on the relationship connecting school's physical environment and performance of the students in Chicago [11]. The findings suggested that school physical environment concurrently affected students individually and collectively. The study also exposed the fact that most of the variations in the scores from school physical environment were within schools. Additionally, perceptions of each student on the physical environment were more strongly linked to improved student outcomes than in collective categorization, particularly students' perceptions of teachers' prospects and school safety. However, more between-school variance in students' academic and behavioural performance was explained by aggregate ratings of schools' physical environment than withinschool variance by individual ratings. Limited, yet positive, support was found for the likelihood that aggregate insight on physical environment moderated the connection of individual perceptions and student performance.

The findings further concurred with those of Owoeye and Yara on the number of learners in a class and academic attainment of secondary school in Ekiti State, Nigeria [12]. The results indicated that there was no significant disparity in the academic outcomes when students were in smaller or in larger classes from urban schools $(\mathrm{t}=1.49 ; \mathrm{p}<0.05)$. It also became clear that there was no significant difference between achievements obtained by students from rural bigger and rural smaller classes $(\mathrm{t}=0.58 ; \mathrm{p}<0.05)$.

Lastly, the findings were also in support of Mwango's on school physical environment influence on pupils' outcomes at the Kenya Certificate of Primary education (KCPE) in Machakos District Central Division, Kenya [21]. The findings indicated that the condition of infrastructure in the school, enough teaching/learning resources, mutual relationships between students and safety procedures when provided can influence performance in KCPE positively. The study vividly indicated that $62 \%$ of the respondents reported that the infrastructure in their school needed improvement without delay, $83 \%$ averred that their teaching/learning resources required immediate improvement, $61 \%$ said that their interpersonal associations needed urgent improvement, and lastly $41 \%$ thought safety measures needed to be made better urgently.

\section{CONCLUSION}

From the research results, it is concluded that the status of the physical infrastructure has no effect on indiscipline cases among secondary school students in Eldoret East Sub-County. Therefore, it is recommended that schools with limited resources should put more emphasis on school regulation, order and student teacher relationships to reduce problem behaviour. 


\section{REFERENCES}

1. Muratha MM. School based factors and their effect on discipline in Secondary schools in Kiambu East District (M.Ed. Thesis). Kenyatta University. 2013.

2. Peterson R, Skiba R. Creating school climates that prevent school violence. Journal of Social Studies. 2011;92(4), 167.

3. UNESCO. Educating Teenagers. Education Today, 4. UNESCO. 2003.

4. Wang MT, Selman RL, Dishion TJ, Stormshak EA. A tobit regression analysis of the covariation between middle school students' perceived school climate and behavioural problems. Journal of Research on Adolescence. 2010;20(2), 274-286.

5. Malinen OP, Savolainen H. The Effect of Perceived School Climate and Teacher Efficacy in Behavior Management on Job Satisfaction and Burnout: A Longitudinal Study. Teaching and Teacher Education. 2016;60, 144-152.

6. Katz M, Blagg K. Evaluating School Climate and Discipline Tools for Parents, Schools, and Policymakers. International Journal of Current Research. 2016;7(9), 210-215.

7. Cornell D, Shukla K, Konold RT. Authoritative School Climate and Student Academic Engagement, Grades, and Aspirations in Middle and High Schools. Journal of AERA Open. 2016;2(2), 1-18.

8. National School Climate Council. The School Climate Challenge: Narrowing the gap between school climate research and school climate policy, practice guidelines and teacher education policy. 2007. Retrieved from http://www.schoolclimate.org/climate/documents/p olicy/ school-climate-challenge-web.pdf

9. Branham D. The wise man builds his house upon the rock: The effects of inadequate school building infrastructure on student attendance. Social Science Quarterly. 2004;85(5), 1112-1128.

10. Cuyvers K, De Weerd G, Dupont S, Mols S, Nuytten C. Well-Being at Schook: Does Infrastructure Matter? CELE Exchange Centre for Effective Learning. OECD Publishing. 2011.

11. Zander, K. Relationships between School Climate and Student Performance: School- and Student- level Analyses (Unpublished MA Thesis). University of Illinois at Chicago. 2015.

12. Owoeye JS, Yara PO. School Facilities and Academic Achievement of Secondary School Agricultural Science in Ekiti State, Nigeria. Asian Social Science. 2011;7(7), 64-73.

13. Mwaura WR. Effectiveness of Kenya education sector support programme grants on primary school infrastructure improvement: a case of Kiambu District (M.Ed.). Kabarak University; 2011.

14. Republic of Kenya.Kenya Education Sector Support Programme (KESSP) 2005-2010. Nairobi: Government Printers. 2005.

15. Ministry of Education. Safety Standards Manual, 5th ed. Nairobi: Ministry of Education. 2008.

16. Kiumi JK, Bosire J, Sang AK. Relationship between principals' management approaches and students' discipline in public secondary schools in Nyandarua and Laikipia districts, Kenya. Global Journal of Educational Research. 2009;8(1-2), 2938.

17. Linares DS. Effects of School Climate on Student Achievement and Discipline Behaviours in Three Urban High Schools (Unpublished Doctor of Education Thesis). University of Houston; 2012.

18. Wairagu WR. School related factors influencing students discipline in public secondary schools in Thika West Sub County, Kenya (Unpublished M.Ed. Thesis). University of Nairobi. 2017.

19. Okendo EO, Nganzi C, Munyua JK. Relationships between School Climate and Students' Academic Achievement in KSCE Examinations: A Case of Kisii County-Kenya. International Journal of Education Learning and Development. 2014;2(5), 7-17.

20. Krejcie RV, Morgan D. Determining Sample Size for Research Activities. Educational and Psychological Measurement. 1970;30(3), 608.

21. Mwango JN. Influence of School Climate on Pupils' Performance at Kenya Certificate of Primary Education in Central Division of Machakos District, Kenya (Unpublished M.Ed. Thesis). University of Nairobi; 2017. 